\title{
ENTRE LA NEUTRALIDAD Y EL COMPROMISO PATRIÓTICO: los escritos de Paul Groussac en Le Courrier de la Plata durante la Gran Guerra
}

Between neutrality and the patriotic commitment: the writings of Paul Groussac in Le Courrier de la Plata during the Great War

\section{RESUMEN}

Este artículo analiza las colaboraciones de Paul Groussac (1848-1929) en el Le Courrier de la Plata, el principal diario de la comunidad francesa de Argentina, durante los años de la Gran Guerra. En esta incursión en la prensa étnica francesa Groussac publicó más de sesenta artículos dedicados a diversas temáticas que, junto con su correspondencia y otros materiales provenientes de su archivo personal e institucional, constituyen las fuentes principales de este trabajo. Por su doble condición de ciudadano francés nacionalizado argentino y como funcionario público de un Estado neutral frente al conflicto bélico, los artículos de Groussac en Le Courrier de la Plata están marcados por una tensión no resuelta entre los deberes de la neutralidad y su abierto compromiso con la causa de Francia. Asimismo, puestas en diálogo con el itinerario intelectual y periodístico del director de la Biblioteca Nacional, estas intervenciones en la prensa étnica revelan no sólo una activa recepción de ciertos trazos de la "cultura de guerra" francesa en el Río de la Plata sino también la actualización de una serie de temas idiosincráticos de la producción de Groussac como la cuestión de la extranjería y el antinorteamericanismo.

Palavras-chave: Paul Groussac, Gran Guerra, Prensa francófona, Le Courrier de la Plata, Buenos Aires.

\section{ABSTRACT}

This article analyzes the collaborations of Paul Groussac (1848-1929) in Le Courrier de la Plata, the main newspaper of the French community in Argentina, during the years of the Great War. In this new incursion into the French ethnic press, Groussac published more than sixty articles dedicated to several topics that, together with his mailing and other materials from his personal and institutional archive, constitute the main sources of this work. Because of his double status as a French citizen nationalized Argentine but also as a civil servant of a neutral State in the war, the articles of Groussac in Le Courrier de la Plata are marked by a tension between the duties of neutrality and his open commitment to the cause of France. However, when they dialogue with the intellectual and journalistic itinerary of the president of the National Library, these interventions in the ethnic press reveal not only an active reception of the French "culture of war" in the River Plate but also the updating of a series of idiosyncratic themes of Groussac's production, such as the question of alien status and anti-Americanism.

Keywords: Paul Groussac, Great War, French press, Le Courrier de la Plata, Buenos Aires. 
Paul Groussac (Toulouse, 1848 - Buenos Aires, 1929) fue una de las figuras más destacadas del espacio cultural porteño entre finales del siglo XIX y comienzos del XX. ${ }^{1}$ Entre los legajos que contiene su archivo personal se halla un telegrama remitido por el Presidente del Consejo de Ministros de Francia, Georges Clemenceau, con quien Groussac había estado en contacto durante su visita a Buenos Aires en tiempos del Centenario. Transmitido por la Western Telegraph Company el 31 de enero de 1918, en este telegrama Clemenceau le anunciaba al director de la Biblioteca Nacional: "V. ETES NOMME OFFICIER LEGION D HONOR FELICITACIONS AMITIES”. ${ }^{2}$ La llegada de la noticia sobre esta distinción - que, en rigor, implicaba un ascenso en el rango de la Orden pues Groussac ya había sido designado Chevalier de la Legión de Honor en 1911 - fue ampliamente celebrada en los círculos de la comunidad franco-argentina de Buenos Aires. ${ }^{3}$ En gran medida, esta condecoración era una recompensa por la activa militancia cultural en favor del Hexágono que el director de la Biblioteca Nacional llevó adelante durante los años de la Gran Guerra. ${ }^{4}$ Y, al mismo tiempo, su ascenso en la Orden implicaba también una ratificación de la estima hacia su figura en el marco de una profunda división al interior de la comunidad francesa de Buenos Aires motivada, entre otros aspectos, por las diferencias en la interpretación de la ley militar francesa durante la guerra. ${ }^{5}$

Esa campaña proselitista tuvo uno de sus ejes principales en los escritos publicados por Groussac entre finales de 1916 y mediados de 1919 en Le Courrier de la Plata, el diario más importante de la colectividad francesa en Argentina. ${ }^{6}$ No era esta la primera vez que Groussac participaba en la prensa étnica; en 1893 tuvo una colaboración episódica en este mismo diario con una serie de crónicas de su viaje a la Exposición Universal de Chicago y, posteriormente, fue la figura central en la efímera experiencia de Le Journal Français (1894-1895), un periódico financiado por Clodomir Hileret, pionero de la industria azucarera en Tucumán, que había conocido al futuro director de la Biblioteca Nacional en su paso por dicha provincia entre 1871 y 1882 (BRUNO, 2005, p. 47-48).

No obstante, en esta nueva incursión en la prensa de la comunidad francesa, la voz de Groussac adquirió un lugar mucho más preponderante si se considera el espacio otorgado por la redacción de Le Courrier de la Plata a sus escritos, publicados el día más importante de la semana para la mayoría de los diarios: los domingos. Esa preeminencia se explica no sólo por la consagración intelectual que Groussac había alcanzado en los años previos a la Gran Guerra sino también porque, a diferencia de los grandes diarios de la Capital Federal, Le Courrier de la Plata no contaba con una vasta red de colaboradores y corresponsales propios. De hecho, este periódico había sufrido una merma en el staff de su redacción y sus talleres como consecuencia de la movilización de los franceses radicados en el extranjero, una ausencia que intentaba ser compensada tomando "prestados" artículos y crónicas de los diversos diarios y revistas que llegaban desde Francia al puerto de Buenos Aires. ${ }^{7}$ Y, por último, porque Groussac expresaba las opiniones del sector de los franco-argentinos que se mostraban reacios a la movilización militar de sus hijos, una posición que encontró en Le Courrier de la Plata uno de sus principales voceros (OTERO, 2009, p. 198). En ese marco, el director de la Biblioteca Nacional, que escapaba a la movilización 
militar por cuestiones de edad (tenía 68 años de edad al momento de comenzar esta nueva participación en Le Courrier...) pero también por el hecho de haber adoptado la nacionalidad argentina en 1909, se hallaba en condiciones ideales para transformarse en una de las figuras destacadas del principal periódico de la colectividad francesa durante la crítica coyuntura de la Gran Guerra.

Hasta su desvinculación definitiva de Le Courrier de la Plata, ocurrida en julio de 1919, Groussac publicó allí más de sesenta artículos dedicados a diversas temáticas que, junto con su correspondencia y otros materiales provenientes de su archivo personal e institucional, constituyen las fuentes principales de este artículo. El propio Groussac realizó una recopilación de buena parte de sus escritos en Le Courrier de la Plata, los cuales tienen el valor agregado de las marcas típicas de los archivos personales como las enmiendas, tachaduras y correcciones realizadas por el autor sobre los textos ya publicados en el diario, lo que revela la intención (nunca concretada) de realizar el pasaje a libro de estos artículos. ${ }^{8}$

Sin embargo, esos recortes no pueden reemplazar a la lectura directa de las páginas del diario en un estudio que pretenda situar el análisis de los vínculos entre intelectuales y periódicos en el marco de la historia cultural y literaria de la prensa. ${ }^{9}$ La remisión a las fuentes originales permite advertir, en primer lugar, que los recortes guardados por el autor no constituyen la totalidad de sus columnas publicadas en Le Courrier de la Plata durante la Gran Guerra y que con frecuencia presentan imprecisiones o directamente carecen de indicaciones sobre sus fechas de publicación. Y, en segundo lugar, la lectura de los artículos en su soporte original brinda la posibilidad de analizar esos escritos sin aislarlos del contexto discursivo que conformaba el medio periodístico en el cual fueron originariamente publicados. Esta perspectiva permite trazar vínculos con otras secciones del diario (las notas dedicadas a la Gran Guerra, las columnas de opinión y los editoriales de actualidad) y de esta manera advertir cómo los textos de Groussac dialogan y condensan una serie de tópicos y debates más amplios presentes en la prensa y la opinión pública de Buenos Aires. Por último, como se verá en el siguiente apartado, este abordaje permite explicar con mayor precisión los alcances de la participación del director de la Biblioteca Nacional en el citado diario y su relación con los conflictos internos de la colectividad francesa de Buenos Aires durante la Primera Guerra Mundial.

Por su condición de ciudadano francés nacionalizado argentino pero también por tratarse de un funcionario público de un Estado formalmente neutral frente al conflicto bélico, los escritos de Groussac en Le Courrier de la Plata están marcados por una tensión irresuelta entre los deberes de la neutralidad y su abierto compromiso con la causa de Francia. ${ }^{10}$ Esa tensión se manifestó en un solapamiento entre dos autofiguraciones muy recurrentes en el itinerario de Groussac: por un lado, la del erudito literato francés o el savant, construida desde finales del siglo XIX como parte de su estrategia de inserción y legitimación en los círculos académicos e institucionales de Argentina. Y, por el otro, la del intelectual en un sentido más estricto, vinculada a formas mucho más concretas de compromiso e intervención en la esfera pública. 
Ahora bien, a diferencia de lo sucedido durante la Gran Guerra con buena parte de los intelectuales y académicos franceses, que pusieron sus conocimientos y saberes al servicio de la causa patriótica, Groussac trató de mantener delimitadas ambas facetas en sus intervenciones periodísticas. ${ }^{11}$ De esta manera, su perfil erudito y, más concretamente, su faceta como historiador, emerge en diversos artículos de carácter divulgativo publicados en Le Courrier de la Plata, dedicados a los viajeros, políticos, militares y científicos franceses que participaron activamente de las guerras de independencia en el Río de la Plata pero también durante el período rivadaviano y el rosismo como Fréderic de Brandsen, Hippolyte Bouchard y Amboise Cramer, entre otros. ${ }^{12}$ En estos artículos, concentrados mayoritariamente en los primeros meses de su colaboración en Le Courrier..., impera un tono pedagógico utilizado con frecuencia por Groussac en sus trabajos históricos y, más allá de señalar el aporte político e intelectual de Francia en los orígenes de la República Argentina, carecen de referencias directas a la conflagración europea. A ellos podrían agregarse, también, el comentario ocasional de algún libro de reciente publicación y las crónicas de sus viajes por Argentina en el período estudiado. ${ }^{13}$

El resto de sus escritos periodísticos publicados en el diario de la comunidad tratan directa o indirectamente sobre temas de actualidad, en especial, sobre la guerra que por entonces asolaba a Europa y cuyas repercusiones llegaban incluso hasta ciudades tan distantes del teatro de operaciones como Buenos Aires. A diferencia del culto por la polémica al que Groussac había apelado como estrategia para adquirir visibilidad en el escenario cultural porteño de finales del siglo XIX, sus escritos en Le Courrier la Plata no tuvieron ese afán polémico ni tampoco motivaron abiertas discusiones con otras publicaciones o intelectuales del ámbito local. ${ }^{14}$ En cambio, sus intervenciones en el diario de la comunidad francesa permiten advertir una continuidad más destacada de su perfil como mediador cultural, situando a Groussac como un activo receptor de ciertos trazos de la "cultura de guerra" y la propaganda francesa en el Río de la Plata. ${ }^{15}$ Sin embargo, en esa circulación transnacional de representaciones sobre el conflicto europeo los actores locales no representaron un mero papel de receptores pasivo. De hecho, los artículos de Groussac escritos al calor de la contienda revelan también la reactualización de una serie de temas idiosincráticos de su pensamiento como la cuestión de la extranjería y su virulento antinorteamericanismo.

Por último, el análisis de los escritos de Groussac en el marco del clima cultural que prevalece en el seno de la prensa y la opinión pública de Buenos Aires durante la Gran Guerra permite cuestionar la etiqueta de intelectual "aliadófilo" atribuida al director de la Biblioteca Nacional (WEINMANN, 1994, p. 62). Dada las particularidades de su discurso sobre la guerra difícilmente pueda considerarse a Groussac como un "aliadófilo" si se entiende por ello a las publicaciones periódicas o intelectuales que expresaron públicamente una defensa irrestricta de las posiciones y los intereses del conjunto de países que integraban la Triple Entente. Esta perspectiva solo se mantuvo de forma incondicional en las publicaciones de propaganda creadas en el transcurso del conflicto como La Acción Francesa (1915) e Idea Nacional (1917) y, en menor medida, en algunos diarios como Crítica, el vespertino dirigido por Natalio Botana que sufrió las consecuencias económicas de su radical postura (SAÍTTA, 1998, 
p. 41-42; SANCHEZ, 2015). En ese marco, los escritos de Groussac revelan ante todo una defensa de Francia y no de la Triple Entente, lo que permite situar a la francofilia que caracterizó a un amplio sector de la prensa y la opinión pública porteña como una posición emparentada pero al mismo tiempo autónoma de la aliadofilia, cuyos alcances lejos de encubrirla (COMPAGNON, p. 69) desbordan ampliamente a las simpatías por el Hexágono.

\section{“Notre éminent collaborateur”: Paul Groussac en Le Courrier de la Plata}

Fundado el $1^{\circ}$ de julio de 1865 por Joseph Alexandre Bernheim y publicado ininterrumpidamente hasta septiembre de 1946, Le Courrier de la Plata fue uno de los periódicos más importantes de la colectividad francesa en Argentina y en el Río de la Plata. ${ }^{16}$ A mediados de 1914, el diario contaba con una redacción e imprenta propias instaladas en la calle Corrientes 549, en una de las manzanas más importantes del denominado "barrios de los diarios", epicentro de las espontáneas concentraciones de los lectores porteños que se agolpaban ante las oficinas de los periódicos para conocer las últimas novedades telegráficas que éstos colocaban en unas pizarras dispuestas para tal fin en el hall de entrada y las ventanas de sus redacciones (SANCHEZ, 2018, p. 181-189). Si bien, las fuentes disponibles no brindan una información fehaciente sobre la evolución de su tirada durante los primeros años del conflicto bélico es posible conjeturar que los meses iniciales de la Gran Guerra constituyeron un momento complejo para Le Courrier de la Plata. En primer lugar, porque el ya señalado desmembramiento de la redacción y de sus talleres fruto de la movilización militar, alcanzó también a otros sectores de la colectividad que, ante el escenario de incertidumbre ocasionado por la guerra y a pesar de los riesgos que implicaba el cruce del Atlántico, decidieron regresar a Francia donde residía parte de sus familias, ocasionando así una pérdida sensible de sus abonados. En segundo lugar, por la compleja situación financiera que atravesaba el Banco Francés del Río de la Plata, administrador de la sociedad anónima que editada Le Courrier..., la única entidad que no logró reabrir sus puertas luego de la semana de feriado cambiario y bancario decretado por el gobierno conservador de Victorino de la Plaza a comienzos de la guerra para neutralizar el peligro de una posible corrida bancaria en Buenos Aires (SÁNCHEZ, 2018, p. 190-191). ${ }^{17}$

Pocos años después, hacia finales de la Gran Guerra, en su informe sobre la industria gráfica de la región, Robert Barrett (1918, p. 35) estima una tirada aproximada de 5000 a 3000 ejemplares mientras que ya en la inmediata postguerra, Luis Maisonnave (1920, p. 13) le atribuye una tirada de 18.000 ejemplares. Estas cifras situaban a Le Courrier de la Plata lejos de los índices de los grandes diarios como La Prensa y La Nación, que según las mismas estimaciones oscilaban entre 200.000 y 165.000 ejemplares, pero también de otros periódicos de colectividades como La Patria degli Italiani, cuyas tiradas se estimaban entre los 50.000 y 40.000 ejemplares aunque, por supuesto, los tirajes de la prensa étnica estaban directamente relacionados con el peso numérico de cada grupo nacional. ${ }^{18}$ No obstante, a pesar de su tirada más bien modesta, la mayor familiaridad con el idioma francés (si se lo compara por ejemplo 
con los diarios escritos en alemán o en ruso) hacía de Le Courrier de la Plata un medio más accesible al público no exclusivamente francés pues era leído también por otros francoparlantes como los belgas y ciertos sectores de la comunidad suiza. Este hecho, sumado a la sensibilidad liberal y republicana que caracterizaba a su línea editorial le otorgaron una mayor llegada a ciertos sectores de las élites y la opinión pública local (OTERO, 2009, p. 91).

Ahora bien, el anuncio de la incorporación de Groussac como colaborador en Le Courrier de la Plata tuvo lugar en diciembre de 1916, cuando la guerra llevaba más de dos años de duración. Esto no implicó, sin embargo, que hasta ese entonces el director de la Biblioteca Nacional no haya manifestado su adhesión a la causa de Francia. De hecho, Groussac había participado en varias veladas organizadas por la colectividad y su nombre figuraba en la lista de suscriptores del Comité Patriotique Française, uno de los principales organismos de ayuda a la patria lejana creados por la comunidad local días después del estallido de la contienda. ${ }^{19}$

Cabría preguntarse, entonces, por qué su llegada al diario se produjo recién a finales de 1916. Ni Groussac ni Le Courrier de la Plata brindan demasiadas explicaciones al respecto. El anuncio de su incorporación como colaborador estable se limita a señalar la promesa realizada por el director de la Biblioteca Nacional de enviar un artículo por quincena, un compromiso que salvo en contadas excepciones (durante unas semanas de reposo a comienzos de 1919 y en el marco de la huelga de los obreros gráficos en junio del mismo año) Groussac cumplió a rajatabla. ${ }^{20}$ De todos modos, existen al menos dos elementos que permiten iluminar las razones de su llegada al diario de la comunidad francesa. En primer lugar, la finalización a comienzos de 1916 de la revista los Anales de la Biblioteca, la segunda experiencia editorial dirigida personal e íntegramente por Groussac y que constituía una suerte de continuación de La Biblioteca (1896-1898). ${ }^{21}$ La pérdida de esta revista, que fuera el ámbito privilegiado por Groussac en sus estrategias de posicionamiento en el ámbito intelectual y académico puede haber impulsado su acercamiento hacia una publicación más polifónica como Le Courrier de la Plata, en la cual a pesar del lugar destacado otorgado a sus escritos el director de la Biblioteca Nacional no constituía el factótum del diario.

En segundo lugar, el ingreso de Groussac al periódico de la colectividad francesa se inscribe en el marco de un recambio en la dirección que trajo consigo una apertura a nuevos colaboradores. Semanas antes el Consejo de redacción del diario había anunciado el reemplazo de su redactor en jefe, Henri Papillaud, que ocupaba este cargo desde 1904, por Charles Doynel, un ingeniero de profesión con una dilatada actuación como miembro del cuerpo consular y que había colaborado en otros diarios porteños como La Nación, El Diario, El País y Le Courrier Français. ${ }^{22}$ De allí, el cariñoso reproche de Groussac en su primera colaboración sobre el anuncio "demasiado halagador" con el que "mi amigo Doynel” comunicó su incorporación al periódico. ${ }^{23}$

Tras refugiarse por unos meses en la redacción de El Diario, el vespertino dirigido por Manuel Láinez, en noviembre de 1917 Papillaud fundó Le Journal Français, una nueva publicación de la colectividad que tuvo como secretario de redacción a Léon Lenain, quien había sido redactor en La Prensa, Le Courrier de la Plata, La Argentina 
y El Diario (PAPILLAUD, 1947, p. 83). En los meses siguientes Le Journal Français mantendrá un intenso debate con Le Courrier de la Plata, dejando en evidencia una fractura en el seno de la comunidad francesa de Buenos Aires.

Esta división estuvo motivada principalmente por un áspero debate en torno a la interpretación estricta o laxa de la ley militar francesa y su interferencia con las leyes argentinas, en el marco de la movilización de los franceses e hijos de franceses radicados o nacidos en el exterior. ${ }^{24}$ Las divergencias sobre este punto impulsaron la conformación de dos grupos que, aunque incubadas desde comienzos del conflicto, adquirieron contornos mucho más definidos en los últimos años de la Gran Guerra. Por un lado, los franco-argentinos, el sector mayoritario de la comunidad que defendía la aplicación de ley argentina con el objeto de evitar la movilización de sus hijos - que contaron con el apoyo de las principales instituciones asociativas de la colectividad, como la Cámara de Comercio y el Club Francés-, y que hicieron de Le Courrier de la Plata su principal vocero. ${ }^{25} \mathrm{Y}$ por el otro, la fracción minoritaria conformada por los llamados "patriotas", es decir, franceses "puros” partidarios de una aplicación estricta de la ley militar francesa, que tuvieron un fuerte respaldo de las autoridades diplomáticas y consulares y que, desde finales de 1917, se nuclearon en torno a Le Journal Français de Henri Papillaud.

Desde su primera colaboración en Le Courrier de la Plata, Groussac dejó en claro su alineamiento con el bando de los franco-argentinos al señalar que uno de los principales objetivos de sus "simpáticas causeries" era el de impulsar un acercamiento entre "dos países cuyos destinos están cerca de mi corazón". ${ }^{26}$ Y si bien, no fue un tema abordado recurrentemente en sus artículos periodísticos, el temor a la movilización de sus hijos varones motivó la escritura de "Las dos Patrias", un drama en tres actos ambientado en los primeros meses de la Gran Guerra. ${ }^{27}$ Esta obra inédita reiteraba el título de una novela de Geoffroy François Daireaux (1908) sobre una temática similar y que posteriormente tendría su expresión en obras literarias como La terre natale de Víctor Margueritte (1917), miembro de la Academia Goncourt y corresponsal del diario La Prensa en París. ${ }^{28}$

La radicalización de la violencia verbal entre ambas fracciones se produjo a partir de un acontecimiento que tuvo a Groussac como uno de sus protagonistas: el homenaje a Francia realizado el 14 de julio de 1918 en el Club Francés de Buenos Aires. Invitado a tomar la palabra en esa velada patriótica, el director de la Biblioteca Nacional pronunció un duro discurso contra los principales aliados del Hexágono (que será analizado en las siguientes páginas) y que motivó una campaña contra el "derrotismo" de Groussac desde las páginas de Le Journal Français (DÍAZ, 2014, p. 58-61; 2018, p. 302-312). Las principales críticas contra Groussac por parte de los sectores nucleados en el diario de Papillaud señalaban, en primer lugar, su renuncia a la nacionalidad francesa como un acto aberrante que inhabilitaría otorgarle a este "renegado" la responsabilidad de tener a cargo el discurso central del día de la toma de la Bastilla. Y, en segundo lugar, el hecho de que mantuviera a sus hijos fuera de las listas de inscriptos que el consulado francés utilizaba para realizar la movilización militar. ${ }^{29}$ 
Semanas después el propio Groussac denunció mediante una carta abierta a Henri Jullemier, ministro plenipotenciario de Francia en Argentina, como el principal responsable de esa campaña de "injurias y calumnias" desde las páginas "del diario que usted patrocina", Le Journal Français, y al que consideraba como "una hoja sin interés, mal escrita, maloliente, y que no tiene otra misión que celebrarlo a usted mismo y a sus compañeros". ${ }^{30}$ Luego de una seguilla de referencias muy peyorativas al ministro (como "tabellion madré") y a "su" diario, Groussac le solicitaba que pusiera fin a las intrigas y discordias que habían ocasionado ese "espectáculo circense". ${ }^{11}$

La respuesta de Jullemier, publicada al día siguiente en Le Courrier de la Plata, muestra un tono menos virulento que el de Groussac. En ella, el ministro brinda su versión sobre los orígenes de Le Journal Français, una publicación que "no es el diario del ministro ni de sus amigos", y tomaba distancia de la acusación de ser el instigador de las críticas contra Groussac. ${ }^{32}$ Según el relato de Jullemier, el periódico fue impulsado, a pesar de sus intentos por disuadirlo, por una fracción minoritaria del Comité Patriotique Français encabezada por Émile Lernoud. Y no obstante reconocer "más simpatías" por los redactores y accionistas de Le Journal Français que por Le Courrier..., eso no lo hacía "su jefe o su inspirador". 33

Este complejo entramado de relaciones y disputas al interior de la comunidad francesa de Buenos Aires, que se manifestaba abiertamente en las páginas de sus principales publicaciones periódicas, permite comprender dos cuestiones. En primer lugar, la insistente mención al patriotismo de Groussac en los homenajes motivados por la entrega de su insignia como Oficial de la Legión de Honor como parte de una disputa discursiva con esos otros sectores de la colectividad. Por ejemplo, durante la fiesta realizada en su honor en el Club Francés, Groussac fue presentado como "nuestro eminente compatriota" por el attaché militar de la Legación de Francia en Argentina, el capitán de infantería colonial Gouspy, quien señaló en presencia del nuevo ministro plenipotenciario Édouard Gaussen: "Usted ha servido notablemente a su país de origen y a su país de adopción". ${ }^{34}$

Y, en segundo lugar, los motivos de la ruptura de Groussac con Le Courrier de la Plata como consecuencia de la introducción de nuevos cambios en su redacción: el regreso de Papillaud como Secretario General de Redacción y la fusión entre ambos diarios de la colectividad francesa respondiendo al "deseo" del ministro Gaussen, inspirado en una pervivencia del clima de Unión Sagrada y un "espíritu de buena voluntad y deferencia recíproca". ${ }^{35}$ Al día siguiente de conocerse esta decisión, el $1^{\circ}$ de julio de 1919, Groussac presentó su renuncia indeclinable ante el Consejo de Administración de La Courrier... ${ }^{36}$ Este hecho, además de iluminar los motivos de la desvinculación del director de Biblioteca Nacional, muestra también los límites de la autonomía de la prensa étnica y la inevitable injerencia que los miembros del cuerpo diplomático y consular ejercían sobre la prensa de las colectividades, sobre todo, en el marco de las campañas propagandísticas que durante la Gran Guerra buscaban ganar el beneplácito no sólo de la colectividad sino también de sectores más amplios de la opinión pública de un país neutral como Argentina. 


\section{Un mediador de la "cultura de guerra" francesa en el Río de la Plata}

El inicio de esta nueva participación del director de la Biblioteca Nacional en Le Courrier de la Plata coincidió con una de las etapas de mayor repercusión de la Gran Guerra en América latina y en Argentina. Esta nueva coyuntura del conflicto bélico estuvo impulsada por el ingreso de los Estados Unidos en la contienda en abril de 1917 como respuesta al restablecimiento de la política alemana de la guerra submarina irrestricta, lo que se tradujo en un notable incremento de las presiones diplomáticas y las acciones de espionaje para que el resto de los países de la región acompañaran la decisión de Washington (COMPAGNON, 2014, p. 141-163; RINKE, 2017, p. 108-160).

En Argentina, esta nueva etapa de la guerra estuvo signada por una escalada de las tensiones diplomáticas a partir del hundimiento, entre abril y junio de 1917, de tres buques de bandera nacional: el Monte Protegido, el Oriana y el Toro. Esta crítica coyuntura adquirió su punto más álgido en septiembre de ese año con el denominado affaire Luxburg, un escándalo diplomático motivado por la filtración de una serie de cables cifrados que el ministro alemán en Argentina el conde Karl Graf von Luxburg había enviado a Berlín y en los que se refería en términos muy despectivos al presidente Hipólito Yrigoyen y a su ministro de Relaciones Exteriores Honorio Pueyrredón, al tiempo que recomendaba a las autoridades alemanas continuar con el hundimiento de los buques argentinos aunque "sin dejar rastros" (MARTIN, 1967, p. 193-263; TATO, 2017, p. 119-139). Cuando estos telegramas llegaron a las páginas de la prensa de Buenos Aires, se desató una activa movilización de la opinión pública que, en su amplia mayoría, buscó modificar el rumbo de la política exterior del gobierno radical y forzar el ingreso de Argentina en la Gran Guerra, un cambio de posición oficial que finalmente no ocurrió.

En ese contexto, al que los diarios porteños dedicaron regueros de tinta, Groussac evitó emitir opiniones directas sobre la política exterior del gobierno radical y aludió muy tangencialmente a esta crisis política ocasionada por la guerra, probablemente por su condición de funcionario público que debía respetar la neutralidad formal del Estado argentino ante el conflicto. ${ }^{37}$ En este sentido, cabe recordar que en las primeras semanas de la Gran Guerra, en el marco de la fascinación provocada por el estallido del conflicto en Buenos Aires, el gobierno argentino emitió una serie de circulares y notificaciones que establecían la prohibición de opinar públicamente sobre la guerra europea y de colaborar en la prensa periódica a los militares, los miembros del cuerpo diplomático e incluso a los maestros y profesores con el objetivo de contener la inevitable manifestación de sus simpatías por alguno de los países beligerantes. ${ }^{38}$

Si bien, el acatamiento de estas resoluciones tuvo sus altibajos - como muestra la polémica en torno a la batalla del Marne que a finales de 1915 protagonizaron el general José Félix Uriburu, director de la Escuela Superior de Guerra, y Raimundo Manigot, jefe de redacción del periódico de propaganda La Acción Francesa - el caso de Groussac revela una cierta tolerancia gubernamental ante esta faceta pública del funcionario. ${ }^{39}$ En efecto, las decenas de circulares del Ministerio de Justicia e Instrucción Pública conservadas en el archivo de la Biblioteca Nacional no permiten 
detectar ningún llamado de atención, al menos oficial, sobre la activa participación de Groussac en la prensa de la colectividad francesa durante la guerra.

Tal vez por ello, sus escritos periodísticos del período aquí estudiado se destacan ante todo por el énfasis puesto en la dimensión europea del conflicto, aspecto en el que Groussac funcionó, al igual que otros intelectuales locales, como un activo mediador cultural entre Francia y Argentina, poniendo en circulación diversos trazos de la "cultura de guerra" francesa, un discurso de tono patriótico y redentor ante la invasión extranjera que, al mismo tiempo, situaba a Francia como el faro de la civilización occidental y la cuna de las libertades democráticas. Esa mediación es evidente en su caracterización general de la guerra, que retoma una serie de tópicos provenientes de la propaganda aliada por ese entonces muy extendidos en Argentina como, por ejemplo, la lucha de razas, el enfrentamiento entre dos paradigmas civilizatorios antagónicos - la Kultur germana versus la Civilisation francesa - y, por último, la cruzada de la libertad, la democracia y la latinidad contra la "barbarie teutona" (COMPAGNON, 2014, p. 84; RINKE, 2017, p. 86-87; TATO, 2017, p. 30-31). En un artículo publicado en marzo de 1918, en el clamaba venganza por un nuevo raid de los aviones alemanes sobre París que había causado la muerte de varios civiles, Groussac afirmaba:

Esta furia destructiva de nuestros enemigos empujados a
la ceguera es sólo la erupción externa que, desde Arminio,
constituye la base de su naturaleza brutal y que se transmite de
padre a hijo. Es en ella que radica, constantemente renovado,
el germen del conflicto milenario entre el feroz y resentido
Germano, y el Galo batallador pero inconsciente: un odio
inexplicable del primero contra el segundo (...) No debemos
confundir (...) este antagonismo racial, orgánico e inextirpable, con
otras enemistades nacionales, circunstanciales y transitorias. ${ }^{40}$

Desde esta perspectiva esencialista, la Gran Guerra queda reducida a un enfrentamiento milenario entre germanos y franceses como una suerte de réplica moderna de la "irritación de Calibán contra Próspero", los antagónicos personajes de La Tempestad de William Shakespeare, una analogía que Groussac ya había utilizado a finales del siglo XIX en el marco de la guerra hispano-norteamericana de 1898 (BRUNO, 2012, p. 57-58)..$^{41}$ No obstante, en otros de sus artículos la Gran Guerra es considerada también como una reactualización de los enfrentamientos bélicos entre ambos países durante el siglo XIX como las guerras napoleónicas y la más reciente guerra franco-prusiana de $1870 .{ }^{42}$

Insertas en el marco de una campaña tendiente a la deshumanización del "enemigo alemán", cuyos orígenes se remontan a la temprana recepción en la prensa de Buenos Aires del complejo entramado de representaciones sobre las "atrocidades alemanas" cometidas en el marco de la invasión de Bélgica en 1914 (SÁNCHEZ, 2015), estas imágenes buscaban moldear entre los lectores porteños una representación peyorativa de Alemania y sus líderes como "bárbaros", "salvajes", "ladrones" y "sanguinarios" (HORNE; KRAMER, 2001). ${ }^{43}$ Aunque por momentos trató de mostrarse algo distante de estas simplificaciones, utilizando un tono menos virulento del que imperaba en 
las páginas de Le Courrier de la Plata y en otras publicaciones de propaganda aliada que se editaban en Buenos Aires, los escritos Groussac apelaron con frecuencia a términos despectivos como "Boches" para referirse a los alemanes y a otros giros como "dignos descendientes de los Vándalos y los Hunos" y "modernos barbaros en plena regresión ancestral". ${ }^{44}$ Tampoco fue reacio a las frecuentes equiparaciones del káiser Guillermo II con otros líderes de los pueblos "bárbaros" como Atila o con Nerón, en alusión al tristemente célebre incendio de la biblioteca de la Universidad de Lovaina. ${ }^{45}$

Esta imagen despectiva de Guillermo II y de sus aliados contrasta con el elogioso tratamiento de ciertos líderes políticos y militares franceses como Georges Clemenceau - en cuyo honor se erigió un busto en el Club Francés de Buenos Aires realizado por el escultor François Léon Sicard (autor del altar dedicado a la Convención Nacional en el Panteón de París) luego de una campaña que tuvo a Groussac como uno de sus principales impulsores $-{ }^{\mathbf{4 6}}$ y el Mariscal Ferdinand Foch, héroe de la "epopeya del Marne" que "salvo a la patria y la civilización" del peligro alemán. ${ }^{47}$

El contraste entre la imagen del genio francés y la superioridad de la civilización latina frente a esa insistente representación de la Alemania "bárbara" como una nación de reciente formación, unificada bajo el doble comando del ejército prusiano y sus universidades, se manifestó también en una crítica a la ciencia y a los académicos alemanes que, en su inmensa mayoría, habían firmado el "grotesco manifiesto de sus 93" y que colaboraron en la campaña de mentiras iniciada para salvaguardar el honor de Alemania luego de que se difundieran en el mundo entero las "atrocidades" cometidas por sus ejércitos durante la invasión de Bélgica. ${ }^{48}$ Esa crítica a los intelectuales y académicos alemanes se mantendrá hasta finales de la guerra como puede verse en su artículo dedicado a Maximilian Harden, ese "enfant terrible del pangermanismo", y a las oscilaciones políticas de su revista Die Zukunft, un "órgano de escándalo y falsedad" que no superaba el rango de la "petite presse de difamación y de chantaje", que por ese entonces daba un tibio apoyo a la incipiente República de Weimar. ${ }^{49}$

Si bien, como ya se ha señalado, buena parte de estas representaciones y discursos provenían de la Europa en guerra, el caso de Groussac no puede reducirse a una mera recepción y reproducción pasiva de estas representaciones. Por el contrario, los artículos publicados por el director de la Biblioteca Nacional en Le Courrier de la Plata revelan una original combinación de estas imágenes elaboradas al calor del conflicto con recurrentes referencias a ciertas figuras de la política y la literatura francesa del siglo XIX como Alphonse de Lamartine, Ernst Renán, Edouard Quinet, Víctor Hugo y Paul Gautier pero también a publicaciones como la Revue Hebdomadaire o la Revue de Deux Mondes. Estos cruces y combinaciones revelan una particular adaptación de ciertos trazos de la "cultura de guerra" francesa y la propaganda aliada con las antiguas referencias intelectuales de Groussac. A su vez, evidencian la continuidad de la estrategia bifronte de presentarse como "un intelectual francés" o "un letrado europeo" en Buenos Aires, a la que apeló sistemáticamente tras su frustrante viaje a Europa en 1883 (BRUNO, 2005, p. 115). El uso de su extranjería le permitió a Groussac no sólo situarse en el ámbito cultural porteño de finales del siglo XIX como el portador 
y el posible difusor de una serie de saberes y novedades europeos sino también configurar un "nosotros", los intelectuales franceses en Argentina. Ambas dimensiones de ese perfil intelectual se mantuvieron en sus escritos periodísticos de los años de la Gran Guerra como puede observarse, por ejemplo, en el extenso artículo dedicado a glosar, para los lectores del Courrier de la Plata, las últimas novedades de la literatura de guerra francesa ${ }^{50}$ y en el uso reiterado del término "nuestro/a" para hacer alusión a Francia y no a la Argentina, a pesar de la ya señalada decisión de naturalizarse argentino en 1909. ${ }^{51}$

\section{Groussac ante la aurora rusa}

Eclipsada por la trascendencia otorgada a la crisis diplomática de 1917, la Revolución Rusa ha ocupado un lugar secundario en los recientes estudios sobre las repercusiones de la Gran Guerra en Argentina (COMPAGNON, 2014, p. 179-180). Sin embargo, lejos de ser un fenómeno marginal o acotado al universo de las izquierdas, los acontecimientos de 1917 tuvieron un rápido e importante impacto en la prensa y la opinión pública local. Las primeras lecturas sobre la Revolución Rusa en la prensa de gran tirada, los semanarios ilustrados y la prensa étnica de las naciones beligerantes tendieron a ubicarla como un proceso político cuyas implicancias eran inseparables del marco general de la Gran Guerra. Estas lecturas iniciales se complementaban, a su vez, con una interpretación de ese proceso revolucionario como un fenómeno eminentemente europeo, carente de una inmediata implicancia local. La emergencia de una percepción sobre las repercusiones o influencias locales de la Revolución Rusa y del "peligro maximalista" en Buenos Aires fue el resultado de un cambio paulatino detectable desde mediados de 1918 que se cristalizó con la llamada Semana Trágica de enero de 1919.52

La dimensión de Groussac como un mediador entre Francia y Argentina en tiempos de la Primera Guerra Mundial pueden advertirse también en su caracterización de los acontecimientos revolucionarios que tuvieron lugar en Rusia. Según la interpretación más consensuada en un importante sector de la prensa periódica porteña más afín a los aliados de la Entente, el proceso revolucionario iniciado en febrero/marzo de 1917 constituyó el comienzo de una serie de reformas parlamentarias y liberales que colocaban a Rusia en la senda de la democracia liberal moderna. Desde esta perspectiva, los acontecimientos de febrero permitían dejar atrás a ese aliado incómodo que era la Rusia zarista y reafirmar así una interpretación de la contienda como un choque entre dos paradigmas civilizatorios antagónicos que enfrentaba a los países representantes de la Democracia, la Justicia y el Derecho contra la "Barbarie" y el despotismo característicos de Alemania y sus aliados. En este sentido, el escenario ruso de comienzos de 1917 reactualizaba una mirada maniquea sobre la guerra que había emergido años atrás en el marco de la campaña contra las "atrocidades alemanas" en Bélgica, reforzada ahora por el ingreso de los Estados Unidos en la contienda y la llegada de las primeras noticias sobre las reformas iniciadas por Alexander Kérenski, que renovaban el espíritu de "cruzada democrática" con el que los aliados presentaban el conflicto. 
El énfasis en esta dimensión "democrática-parlamentaria” de la revolución de febrero explica que, a pesar del halo de imprecisión y la falta de información fehaciente, las primeras interpretaciones de los acontecimientos revolucionarios de octubre/noviembre de 1917 señalaran con insistencia la idea de un "golpe de Estado" protagonizado por los líderes bolcheviques y sus adeptos. Con el correr de las semanas, a medida que se estabilizaba la información procedente del exterior, emergió una mirada mucho más crítica sobre esta nueva etapa del proceso revolucionario fundada en el accionar de los bolcheviques frente a la Gran Guerra, y más concretamente, en la firma de la paz por separado con Alemania que, a ojos de los aliados de la Entente y sus partidarios locales implicaba la liberación del frente oriental para Alemania. El énfasis en la política exterior de los revolucionarios por sobre su programa político interno y la puesta en marcha de las primeras medidas del gobierno revolucionario fue una de las marcas distintivas de las primeras representaciones iniciales de la Revolución Rusa, asociadas a una rápida recepción y adaptación local de las lecturas de la propaganda aliada sobre los bolcheviques como "agentes alemanes", pagados por el oro de Berlín.

Elaborada mediante una combinación de la información internacional proveniente de las agencias de noticias aliadas, en particular de la francesa Havas, y las colaboraciones de algunos miembros de su redacción, esa mirada sobre la Revolución Rusa tuvo una amplia acogida en las páginas de Le Courrier de la Plata. ${ }^{53}$ Sin embargo, la mirada de Groussac sobre los inicios de ese proceso revolucionario presenta algunas particularidades que dialogan críticamente con esa extendida interpretación. Para el director de la Biblioteca Nacional, por las circunstancias críticas en la que estalló - en el "año lúgubre" de 1917 en el que Francia debió enfrentar por primera vez una oleada de motines en la zona de Chemin des Dames - la revolución que tenía lugar en Rusia podía considerarse como uno de los hechos más importante de la contienda luego de la batalla del Marne y del ingreso de los Estados Unidos en el conflicto. ${ }^{54}$

Luego de advertir sobre el "conocimiento muy superficial del pueblo ruso" que existía en Buenos Aires, en un artículo publicado a comienzos de 1918, cuando los rumores de la firma de una paz por separado de Rusia con Alemania ocupaban cada vez más espacio en las páginas de la prensa porteña, Groussac brindó una polémica caracterización del proceso revolucionario en el que atribuyó un peso importante a la desaparición de Rasputín, "un vagabundo siberiano, ignorante, vicioso, que estaba pudriéndose en la miseria" antes de comenzar su meteórico ascenso en la corte del zar Nicolás II, y al "partido alemán" que en los últimos años "ha crecido y se ha extendido por todo el imperio. Ejército, universidades, marina, arsenales, bancos, granjas o industriales: todo fue entregado a las garra germana". ${ }^{55}$ Avalando en parte la caracterización más consensuada de la propaganda aliada sobre la revolución, el director de la Biblioteca Nacional sostenía que dicho partido alemán era responsable de la "inesperada defección" del aliado ruso que había demorado más no sepultado el "triunfo de la causa justa" de los aliados de la Entente.

No obstante, el aspecto más polémico de la interpretación de Groussac sobre los acontecimientos ocurridos en Rusia era su señalamiento de ciertas continuidades y semejanzas entre el zarismo y el bolchevismo considerados ambos como formas 
análogas de un mismo "despotismo oriental", detentor de un "poder funesto" y basado en una endémica "corrupción administrativa". ${ }^{56}$ En este sentido, la anarquía causada por el gobierno bolchevique era, para Groussac, "peor que el zarismo" pues podía degenerar en una "barbarie" funcional a la "corrupción generalizada" y la disolución definitiva del Imperio ruso. ${ }^{\mathbf{5 7}}$

Si bien las menciones y los artículos del director de la Biblioteca Nacional dedicados a Rusia son más escasos, estos muestran una interpretación particular que dialoga críticamente con la imagen más extendida de la revolución a partir de una nueva apelación a referencias y categorías decimonónicas para descifrar las características de ese movimiento, como es el caso del "despotismo oriental”, una noción muy extendida en las élites locales entre mediados del siglo XIX y comienzos del XX (BERGEL, 2015, p. 29-68). Esa crítica caracterización del Imperio zarista y de la revolución bolchevique muestra, por un lado, la relativa autonomía de este "eminente colaborador" frente a la línea editorial de Le Courrier de la Plata y, por el otro, reafirma la caracterización de Groussac como a un acérrimo defensor de Francia y no como un intelectual "aliadófilo". Pues en sus escritos no sólo mostró su rechazo hacia Rusia sino que, como se verá en el próximo apartado, también se permitió realizar críticas abiertas a otros aliados del Hexágono como Inglaterra y los Estados Unidos.

\section{Fisuras y continuidades en el antinorteamericanismo de Groussac}

Al igual que buena parte de la afrancesadas élites políticas e intelectuales de la Argentina, desde finales del siglo XIX Groussac manifestó un fuerte antinorteamericanismo como puede verse tanto en las crónicas de su viaje por los Estados Unidos - publicadas primero en el diario La Nación y luego en formato libro como Del Plata al Niágara (1897)- como en sus intervenciones durante la guerra hispano-norteamericana de 1898. Inscriptas en el clima cultural del llamado primer antiimperialismo latino-americano (TERÁN, 1986, p. 85-97), las reflexiones de Groussac sobre la gran nación del norte estuvieron marcadas por la repulsión y el fastidio que le ocasionó su contacto con la sociedad norteamericana. Sus críticas apuntaron a la falta de distinción social de sus élites, sumidas en el más burdo materialismo, a los excesos de una democratización perniciosa que conducía a la tiranía de las mayorías y al igualitarismo y, por último, a su peligroso expansionismo militar sobre América Latina. Estos atributos conformaron una imagen de los Estados Unidos como una nación torpe pero avasallante que Groussac condensó en la rudimentaria figura del mamut (BRUNO, 2012, p. 43-68).

Sin embargo, en el contexto de la Gran Guerra y, en especial, luego del ingreso de los Estados Unidos en la contienda como un aliado que podría traer la ansiada victoria final de la Triple Entente, ese virulento "antiyankismo" debió ser al menos momentáneamente mesurado. En un artículo de julio de 1917, dedicado a reconstruir los vínculos entre George Washington y el Marqués de La Fayette, cuya publicación coincidió con llegada a Buenos Aires de la escuadra norteamericana comandada por el Almirante William B. Caperton, Groussac señalaba la existencia de una suerte de "afinidad electiva" entre Francia y los Estados Unidos. ${ }^{\mathbf{5 8}}$ La figura de La Fayatte y su 
rol en el apoyo a los patriotas norteamericanos le permitió al director de la Biblioteca Nacional encontrar algún aspecto de las relaciones entre ambos países que matizara la polarización entre "latinidad versus yankismo" que Groussac había utilizado con frecuencia durante la guerra de hispano-norteamericana de 1898. No obstante, el texto contiene un cierto dejo de reclamo al señalar que con su ingreso en la guerra "el pueblo del no-intervencionista Monroe" había modificado la orientación tradicional de su política exterior hacia "los principios del derecho y la justicia". ${ }^{59}$ Con esta decisión, los Estados Unidos han cruzado el Rubicón, afirmaba el director de la Biblioteca Nacional, y “el mundo asombrado, después de tres años de catástrofes (...) asiste al prodigioso retorno de la expedición llevada a cabo hace más de un siglo, en ayuda de los 'insurgentes' por La Fayette”. 60

Este tono de recelo se tornará en una crítica abierta en el ya mencionado discurso que Groussac pronunció en el Club Francés de Buenos Aires durante los festejos por el 14 de julio de 1918. En esa ocasión, el director de la Biblioteca Nacional trazó un balance de los cambios más importantes en el decurso de la contienda: por un lado, el colapso de la Rusia zarista, a quien responsabilizó además por el estallido de la Gran Guerra al aludir a la "vergonzosa defección de la potencia que, hace cuatro años, desencadenaba la guerra imperdonable"; y, por el otro, el ingreso de los Estados Unidos en la contienda, "que parece convertirse en un factor decisivo en la última fase de la lucha" y en una "ayuda oportuna" que puede contribuir a "la feliz terminación de la pesadilla que, desde hace cuatro años, oprime a la humanidad" ${ }^{61}$ De esta manera, Estados Unidos abandonaba su "secular política de no intervención y de espléndido egoísmo, con respecto a los conflictos del viejo mundo" de la que habían hecho "un sistema y un dogma político". ${ }^{2}$ Para Groussac, esta decisión implicaba también un cambio drástico en la psicología del pueblo norteamericano, "consagrado al único culto del dios Dólar!”. ${ }^{3}$

Si bien estas críticas reiteraban aspectos que ya habían sido señalados por Groussac a finales del siglo XIX, como el carácter burdo y materialista del pueblo norteamericano y sus líderes, la coyuntura de la Gran Guerra arrojaba también algunas novedades como, por ejemplo, la crítica a los "poderes discrecionales" concedidos a Woodrow Wilson, que transformaban al presidente norteamericano en "un verdadero dictador". ${ }^{4}$ Aunque para Groussac no era posible predecir cuáles serían las consecuencias de esta transformación de las instituciones norteamericanas, en su discurso manifestó, por último, sus temores frente a un posible escenario europeo de la postguerra marcado por la emergencia de "un nuevo imperialismo que sustituirá al pangermanismo bárbaro y entrará en lucha con el imperio británico, en el momento de los conflictos de paz". ${ }^{65}$ Ante ese conflictivo escenario, Groussac instaba a redoblar los esfuerzos para mantener la influencia francesa en América Latina como contrapeso al creciente panamericanismo impulsado desde Washington. Este último aspecto de su discurso es quizás el más significativo, pues Groussac no sólo acusaba al zarismo de haber desencadenado la guerra, contradiciendo la interpretación más consensuada entre los partidarios de los aliados que atribuía esa responsabilidad a Alemania, sino que también denunciaba el carácter imperialista de algunos de los principales aliados de Francia en la contienda: Inglaterra y los Estados Unidos. 
Esa mirada crítica y desconfiada sobre la figura de Wilson y el papel de los Estados Unidos se mantendrá incluso luego de la firma del armisticio y en el marco de la algarabía por la recuperación de Alsacia y Lorena para la patria francesa. ${ }^{66}$ Mientras las páginas de Le Courrier de la Plata daban cuenta diariamente de los avances y retrocesos en las negociaciones de los tratados de paz que tenían lugar en Europa, Groussac volvió a manifestar su desconfianza sobre el rol preponderante de Wilson y de los Estados Unidos en la futura Sociedad de la Naciones. ${ }^{67}$ Para el director de la Biblioteca Nacional - que no ahorraba ya en ironías y epítetos para aludir al presidente norteamericano como un "universitario de Princeton" o el "Buffalo Bill de la diplomacia"- Wilson estaba llevando a cabo una transformación de la doctrina Monroe con el objetivo de usar el drama de la guerra europea en beneficio de los Estados Unidos. ${ }^{68}$

De esta manera, el fin de la Gran Guerra trajo un alivio parcial a las preocupaciones de Groussac al sellar la derrota definitiva del "Kaiserato" y del militarismo prusiano. Sin embargo, los artículos periodísticos publicados en Le Courrier de la Plata durante el conflictivo escenario de la inmediata postguerra revelan los temores persistentes en el director de la Biblioteca Nacional no sólo por la expansión del panamericanismo norteamericano sino también por el incremento del bolchevismo en Europa occidental. A pesar de su apoyo irrestricto hacia las propuestas de Clemenceau en el marco de las negociaciones del tratado de Versalles - al que consideró como "el documento internacional más solemne registrado en el historia" y como "la más gloriosa victoria y la más durable conquista moral de esta espantosa guerra"-Groussac advertía en sus últimos artículos sobre los riegos de esa política extrema sobre la Alemania vencida, "ya contaminada de anarquía por la Rusia bolchevique", que sumada a la miseria y la derrota podrían empujar "a la marea popular contra la república provisoria, sin base ni prestigio" y poner en riesgo el nuevo escenario internacional de la postguerra. ${ }^{69}$

\section{A modo de conclusión}

A pesar de la importancia de la Gran Guerra en la vida de Paul Groussac, esta particular coyuntura no había sido considerada en las investigaciones más recientes sobre esta figura central del escenario cultural porteño del período. El análisis del itinerario y los posicionamientos del director de la Biblioteca Nacional a partir de sus artículos publicados en Le Courrier de la Plata ha permitido constatar la originalidad de las posiciones sostenidas por un intelectual que, a pesar de su obligación de acatar la neutralidad estatal, manifestó una defensa irrestricta de Francia.

Como se ha podido apreciar, esa campaña se sostuvo mediante una serie de representaciones sobre el conflicto procedentes de la propaganda aliada y que permiten situar a Groussac como un activo mediador y difusor de la "cultura de guerra" francesa en Argentina. Sin embargo, sus colaboraciones en Le Courrier... no se limitaron a una mera reproducción de ciertas claves interpretativas sobre la guerra originarias de Europa. Por el contrario, el abordaje de sus artículos periodísticos ha permitido desentrañar también una mirada particular sobre el conflicto que se evidencia tanto en sus críticas a la Rusia zarista y la revolución bolchevique como 
en la continuidad de su intransigente recelo hacia los Estados Unidos y la figura de Wilson. Esta imposibilidad de hacer extensiva sus simpatías al resto de los integrantes de la Triple Entente impide considerar al director de la Biblioteca Nacional como un simple intelectual "aliadófilo"; y revela, a su vez, los matices que emergen al poner en diálogo ciertos casos individuales con el clima cultural que prevalece en la prensa y la opinión pública porteña durante la Gran Guerra.

\section{Referencias}

AUDOIN-ROUZEAU, S.; BECKER, A. Violence et consentement. La "culture de guerre" du premier conflit mondial. In: RIOUX, J. P.; SIRINELLI, J. F. Pour une histoire culturelle. París: Seuil, 1997, p. 251-271.

BARRETT, R. Paper, paper products and printing machinery in Argentina, Uruguay and Paraguay. Special Agents Series, n. 163. Washington: Department of Commerce, 1918.

BERGEL, M. De Sarmiento al positivismo finisecular: la idea de Oriente en el siglo XIX argentino. In: El Oriente desplazado. Los intelectuales y los orígenes del tercermundismo en la Argentina. Bernal: Universidad Nacional de Quilmes, 2015, p. 29-68.

BRUNO, P. Georges Clemenceau en la Buenos Aires de 1910. In: BRUNO, P. Visitas culturales en la Argentina 1898-1936. Buenos Aires: Biblos, 2014, p. 71-95.

Mamuts vs. hidalgos. Lecturas de Paul Groussac sobre Estados Unidos

y España en el fin-de-siglo. In: PITA, A. y MARICHAL, C. (comps.). Pensar el antiimperialismo. Ensayos de historia intelectual latinoamericana 1900-1930. México: El Colegio de México/Universidad de Colima, 2012, p. 43-68.

Paul Groussac. Un estratega intelectual. Buenos Aires: Fondo de Cultura Económica/Universidad de San Andrés, 2005.

CISNEROS, A.; ESCUDÉ, C. Las relaciones con Europa y los Estados Unidos, 18811930. In: Historia General de las relaciones exteriores de la República Argentina. Parte II, Tomo VIII. Buenos Aires: Nuevohacer, 1999.

COMPAGNON, O. América latina y la Gran Guerra. El adiós a Europa (Argentina y Brasil, 1914-1939). Buenos Aires: Crítica, 2014.

DAIREAUX, G. Las dos patrias. Buenos Aires: Biblioteca de 'La Nación', vol. 314, 1908. 
DELPORTE, C. Images d'un montre: le ‘boche'. Grande Guerre et mobilisation visuelle. In: DELPORTE, C. Images et politique en France au XXe siècle. París: Nouveau Monde Éditions, 2006, p. 125-163.

DÍAZ, H. La élite de la colectividad francesa de Buenos Aires: conformación, autonomización y hegemonía política (1902-1919). Tesis de doctorado en Historia Facultad de Filosofía y Letras, Universidad de Buenos Aires, Argentina, 2018.

Patriotismo y derrotismo en la comunidad francesa de Buenos Aires: PolHis. Revista Bibliográfica del Programa Interuniversitario de Historia Política. Buenos Aires, n. 14, p. 53-69, 2014.

HANNA, M. The mobilization of intellect. French scholars and writers during the Great War. Nueva York: Harvard University Press, 1996.

HORNE, J.; KRAMER, A. German atrocities 1914: a history of denial. New HavenLondres: Yale University Press, 2001.

JULIEN, E. À propos de l'historiographie française de la première guerre mondiale. Labyrinthe. Hermann, París, v. 18, n. 2, p. 53-68, 2004.

KALIFA, D.; VAILLANT, A. Pour une histoire culturelle et littéraire de la presse française au XIXe siècle: Le Temps des médias. Nouveau Monde éditions, París, $\mathrm{n}$. 2, v. 1, p. 197-214, 2004.

KALIFA, D.; RÉGNIER, P.; THÉRENTY. M.; VAILLANT, A. La Civilisation du journal. Histoire culturelle et littéraire de la presse française au XIX ${ }^{e}$ siècle. París: Nouveau Monde éditions, 2011.

LANÚS, J. A. Aquél apogeo. Política internacional argentina, 1910-1939. Buenos Aires: Emecé, 2001.

MAISONNAVE, L. El periodismo en la República Argentina. In: Anuario Industrial de la Nación Argentina. Buenos Aires: Benet Editor, 1920.

MARIOT, N. Tous unis dans la tranchée? 1914-1918, les intellectuels rencontrent le people. París: Seuil, 2013.

MARTIN, P. A. Latin America and the War. Massachusetts: Peter Smith, 1967.

MINISTERIO DE RELACIONES EXTERIORES Y CULTO. Documentos y actos de gobierno relativos a la guerra en Europa. Buenos Aires: Ministerio de Relaciones Exteriores y Culto, 1919.

OTEIZA, V. I. Le Courrier de la Plata. Diario de la colectividad francesa rioplatense. Temas de Historia Argentina y Americana. Universidad Católica Argentina, Buenos Aires, n. 8, p. 95-141, 2006.

OTERO, H. Historia de los franceses en la Argentina. Buenos Aires: Biblos, 2012. 
Emigración, movilización militar y cultura de guerra. Los franceses de la Argentina durante la Gran Guerra: Amnis. Revue de civilisation contemporaine Europes/Amériques. Aix-Marseille Université, Aix-en-Provence, n. 10, 2011.

La guerra en la sangre. Los franco-argentinos ante la Primera Guerra Mundial. Buenos Aires: Sudamericana, 2009.

Yrigoyen y la Argentina durante la Gran Guerra según los agregados militares franceses. Estudios Sociales. Revista Universitaria Semestral. Santa Fe, Universidad Nacional del Litoral, n. 36, p. 69-90, 2009.

PAPILLAUD, H. Le Journalisme Française à Buenos Aires de 1818 jusqu'à nos jours. Buenos Aires: Luis Lasserre editor, 1947.

PELOSI, H. C. Las relaciones franco-argentinas 1880-1918: inmigración, comercio y cultura. Buenos Aires: Librería Histórica, 2008.

Publicaciones de la francofilia argentina. Temas de historia argentina y americana. Universidad Católica Argentina, Buenos Aires, n. 1, p. 65-96, juliodiciembre de 2002.

. Argentinos en Francia. Franceses en Argentina. Buenos Aires: Ciudad Argentina, 1999.

PROCHASSON, C. La langue de feu. Science et expérience linguistiques pendant la Première Guerre mondiale. Revue d'histoire moderne et contemporaine. París, v. 3, n. 53, 2006, p. 122-141.

PROCHASSON, C.; RASMUSSEN, A. Au nom de la patrie. Les intellectuels et la Première Guerre mondiale, 1910-1919. París: La Découverte, 1996.

PURSEIGLE, P. A very French debate: the 191-918 "war culture”. Journal of War and Culture Studies. Londres, v. 1, n. 1, p. 9-14, 2007.

REGALSKY, A. Banca e inmigración en Argentina: el Banco Francés del Río de la Plata, 1886-1914: Revista de la Historia de la Economía y de la Empresa. BBVA, Bilbao, n. 6, p. 159-180, 2012.

¿Una experiencia de banca industrial en la Argentina agroexportadora? El Banco Francés del Río de la Plata, 1905-1914. Anuario del Centro de Estudios Históricos "Prof. Carlos S. A. Segreti". Centro de Estudios Históricos "Prof. Carlos S. A. Segreti”, Córdoba, n. 1, p. 215-239, 2001.

RINKE, S. Latin America and the First World War. Nueva York: Cambridge University Press, 2017.

SAÍTTA, S. Regueros de tinta. El diario Crítica en la década de 1920. Buenos Aires, Sudamericana, 1998. 
SÁNCHEZ, E. G. Pasión de multitudes: la prensa y la opinión pública de Buenos Aires frente al estallido de la Gran Guerra. Anuario IEHS. Instituto de Estudios Históricos y Sociales, Tandil, v. 33, n. 1, enero-junio de 2018, p. 177-204.

La invasión alemana de Bélgica y la movilización visual en la prensa de Buenos Aires. Un estudio sobre las imágenes del diario Crítica durante los inicios de la Gran Guerra. Revista Contemporânea. Núcleo de Estudios Contemporáneos, Universidade Federal Fluminense, Río de Janeiro, v. 2, n. 8, julio-diciembre de 2015, p. 1-39.

SMITH, L. The "Culture de guerre" and French Historiography of the Great War of 1914-1918: History Compass. Wiley-Blackwell: Londres, v. 5, n. 6, p. 1067-1079, 2007.

TATO, M. I.M. La trinchera austral. La sociedad argentina ante la Primera Guerra Mundial. Rosario: Prohistoria Ediciones, 2017.

TERÁN, O. El primer antiimperialismo latino-americano (1898-1910). In: En busca de la ideología argentina. Buenos Aires: Catálogos: 1986, p. 85-97.

TERCER CENSO NACIONAL. Levantado el 1 de junio de 1914. Buenos Aires: Talleres Gráficos L. J. Rosso y Cía., tomo IX, 1917.

URIBURU, J. F. La batalla del Marne: apuntes y enseñanzas de la guerra actual. Buenos Aires: M. Schneider, 1918.

La Guerra actual. Apuntes y enseñanzas. Buenos Aires: Sin editorial, 1915.

VÁZQUEZ-PRESEDO, V. El caso argentino. Migración de factores, comercio exterior y desarrollo, 1875-1914. Buenos Aires: Eudeba, 1971.

WEINMANN, R. Argentina en la Primera Guerra Mundial: neutralidad, transición política y continuismo económico. Buenos Aires: Biblos-Fundación Simón Rodríguez, 1994. 


\section{Notas}

1 Para una mirada de conjunto sobre el itinerario intelectual de Groussac (BRUNO, 2005, p. 11-62).

2 Fondo Paul Groussac, Legajo n. 1, Correspondencia recibida (1881-1929), Archivo General de la Nación, Argentina (en adelante, AGN). Se han conservado la ortografía y la puntuación originales en las citas de las fuentes primarias. Todas las traducciones han sido realizadas por el autor. Sobre la visita de Clemenceau a Buenos Aires véase (BRUNO, 2014, p. 71-95).

3 Cf. LA RÉDACTION. Dans la Légion d'Honneur: Le Courrier de La Plata (en adelante, LCLP). Buenos Aires, año 53, n. 216, 1 de febrero de 1918, p. 3; PRUD’HOMME, P. Monsieur Paul Groussac: LCLP. Buenos Aires, año 53, n. 288, 14 de abril de 1918, p. 3 y SIN FIRMA, Cérémonie de la remise des insignes d'Officier de la Légion d’Honneur à M. Paul Groussac: LCLP. Buenos Aires, año 54, n. 141, 19 de noviembre de 1918, p. 3.

4 En una carta en la que lo felicitaba por esta premiación, su "soeur en France", Francisca Jacques -hija de Amadeo Jacques y fundadora del Comité Argentino Pro-Hogar de los huérfanos belgas- narra su negativa a integrar una asociación que contaba con un germanófilo entre sus filas: "Solamente Groussac i usted llevan hasta ese punto la intransigencia”, le manifestó un amigo en común, "Sí, i de ello estoy muy orgullosa". Carta de Francisca Jacques, Buenos Aires, 5 de febrero de 1918, Fondo Paul Groussac, Legajo n. 1, Correspondencia recibida (1881-1929), AGN.

5 Según los datos del Tercer Censo Nacional, realizado en junio de 1914, el grueso de la población extranjera radicada en Argentina se repartía entre las siguientes colectividades: italianos (40,6\%), españoles (36,3\%), rusos (4,1\%), franceses (3,5\%), sirio-libaneses (2,8\%), austro-húngaros (1,7\%), británicos (1,2\%), alemanes (1,1\%) y suizos (0,6\%) (VÁZQUEZ-PRESEDO, 1971, p. 94). Por ese entonces, los franceses de la Argentina constituían la colonia francesa más importante de Latinoamérica. Aunque sus patrones de inserción urbana y rural no fueron muy diferentes del resto de los migrantes europeos que se establecieron en el país, desde el punto de vista social los franceses representaron un caso intermedio entre los grupos más populares, como los italianos y españoles, y los grupos de élite, como los británicos. No obstante, esa menor presencia numérica de los franceses contrasta con su vitalidad y visibilidad en otros planos como la creación de periódicos y asociaciones comunitarias. Otra de las peculiaridades de la colectividad francesa fue su mayor integración a la sociedad argentina impulsada por el alto porcentaje de matrimonios mixtos y la rápida adopción del idioma castellano, entre otros factores. Para un análisis más extenso sobre estos aspectos véase (PELOSI, 1999, p. 19-141; 2008; OTERO, 2009, p. 15-35; 2012; DÍAZ, 2018).

6 El archivo institucional de la Biblioteca Nacional, dirigida por Groussac durante más de cuarenta años años (desde 1885 hasta su muerte en 1929) muestra también algunos contactos con los organismos franceses encargados de la distribución de materiales de propaganda durante la guerra. Cf. Section Photographique et Cinématographique de l'Armée, Carta a M. Paul Groussac, París, 27 de abril de 1917, Fondo Biblioteca Nacional "Mariano Moreno", sección Dirección, serie Correspondencia, caja n. 20 (1916-1917). No obstante, la correspondencia recibida durante los años de la Gran Guerra revela que el envío de ese tipo de libros y folletos no fue exclusivo de Francia.

7 Según el Tercer Censo Nacional, Le Courrier de la Plata contaba con 60 empleados distribuidos de la siguiente manera: 14 en la redacción ( 2 argentinos y 12 extranjeros), 46 entre la administración y los talleres (30 argentinos y 16 extranjeros) (TERCER CENSO NACIONAL, 1917, p. 288-289). Sobre la movilización de la comunidad francesa de Argentina durante la Gran Guerra véase (OTERO, 2009; 2011; DÍAZ, 2018, p. 237-281).

8 Cf. Fondo Paul Groussac, Legajo n. 7, Libro de recortes de periódicos (1886-1928), AGN.

9 Sobre las características de esta perspectiva historiográfica véase (KALIFA y VAILLANT, 2004 y KALIFA, RÉGNIER, THÉRENTY y VAILLANT, 2011, p. 7-21).

10 Cabe recordar que el 5 de agosto de 1914, luego del ingreso de Inglaterra en la contienda, Argentina declaró la "más estricta neutralidad" frente al estado de guerra entre "naciones amigas". Durante la administración conservadora de Victorino de la Plaza -entre la firma de este primer decreto y el 31 de agosto de 1916-, la decisión fue reafirmada en ocho oportunidades a medida que nuevos países se incorporaban al conflicto. Archivo del Ministerio de Relaciones Exteriores y Culto, República Argentina, Sección Primera Guerra Mundial, caja AH0016, “Guerra europea. Medidas de Guerra. Neutralidad”, legajos II 1 al 8. Los decretos pueden consultarse también en el llamado Libro Azul, publicado por el gobierno argentino luego de la guerra (MINISTERIO DE RELACIONES EXTERIORES Y CULTO, 1919, p. 3-33). 
11 La bibliografía sobre este aspecto es muy extensa. Véase, entre otros (HANNA, 1996; PROCHASSON y RASMUSSEN, 1996 y MARIOT, 2013).

12 Véase De Paul Groussac. Le passage des Andes: LCLP. Buenos Aires, año 52, n. 211, 28 de enero de 1917, p. 3; De Paul Groussac. L'action Française en Argentine: LCLP. Buenos Aires, año 52, n. 225, 11 de febrero de 1917, p. 3; De Paul Groussac. Quelques profils de 'brigands expatriés': LCLP. Buenos Aires, año 52, n. 239,25 de febrero de 1917, p. 3; De Paul Groussac. Frédéric de Brandsen: LCLP. Buenos Aires, año 52, n. 253, 11 de marzo de 1917, p. 3; De Paul Groussac. Un complot de Français en 1818: LCLP. Buenos Aires, año 52, n. 267, 25 de marzo de 1917, p. 3; De Paul Groussac. Corsaires français dans La Plata. Hippolyte Mordeille: LCLP. Buenos Aires, año 52, n. 281, 8 de abril de 1917, p. 3; De Paul Groussac. Aimé Bonpland: LCLP. Buenos Aires, año 52, n. 309, 6 de mayo de 1917, p. 3; De Paul Groussac. Hippolyte Bouchard: LCLP. Buenos Aires, año 52, n. 337, 3 de junio de 1917, p. 3; De Paul Groussac. Voyageurs Français en Argentine: LCLP. Buenos Aires, año 53, n. 57, 26 de agosto de 1917, p. 3; De Paul Groussac. De Rivadavia á Rosas: LCLP. Buenos Aires, año 53, n. 71, 9 de septiembre de 1917, p. 4; De Paul Groussac. Au temps de Rosas: LCLP. Buenos Aires, año 53, n. 113, 21 de octubre de 1917, p. 3; De Paul Groussac. À propos de Brandsen: LCLP. Buenos Aires, año 53, n. 155, 2 de diciembre de 1917, p. 3; De Paul Groussac. Trois Pionniers de Progrés: LCLP. Buenos Aires, año 53, n. 169, 16 de diciembre de 1917, p. 3; De Paul Groussac. Amédée Jacques: LCLP. Buenos Aires, año 53, n. 225, 10 de febrero de 1918, p. 3 y De Paul Groussac. Gaston Maspero: LCLP. Buenos Aires, año 53, n. 295, 21 de abril de 1918 , p. 3. Sobre la faceta de Groussac como autor de obras históricas y su aporte a la profesionalización de la disciplina en Argentina (BRUNO, 2005, p. 169-212).

13 Cf. De Paul Groussac. De nuestra tierra: LCLP. Buenos Aires, año 53, n. 1, 1 de julio de 1917, p. 3; De Paul Groussac. Alta Gracia: LCLP. Buenos Aires, año 53, n. 239, 24 de febrero de 1918, p. 3; De Paul Groussac. A la Terre de Feu I: LCLP. Buenos Aires, año 54, n. 208, 26 de enero de 1919, p. 3 y De Paul Groussac. A la Terre de Feu II: LCLP. Buenos Aires, año 54, n. 222, 9 de febrero de 1919, p. 3.

14 En este sentido, cabría señalar como única excepción el altercado con ciertos sectores de la colectividad judía de Buenos Aires con motivo de un artículo publicado luego de la toma de Jerusalén por los aliados y de la famosa Declaración Balfour, en noviembre de 1917. Aunque reconocía que por la complejidad del tema sería más fácil analizarlo en "treinta páginas de revista que en tres columnas de un diario", Groussac se mostraba partidario de la política de asimilación. Por ello, luego de lanzar una serie de críticas a la colonización emprendida por los judíos en las provincias de Entre Ríos, Santa Fe y Buenos Aires con el amparo de la Jewish Colonization Association, Groussac definió al proyecto sionista del Estado judío en Palestina como el "ensueño irresponsable de un quimérico nacionalismo". Cf. De Paul Groussac. Le Sionisme et la prise de Jérusalem: LCLP. Buenos Aires, año 53, n. 183, 30 de diciembre de 1917, p. 3. Este artículo motivó una dura respuesta de la colectividad israelita que equiparaba sus dichos sobre la "indeseable" inmigración judía con las concepciones de Edouard Drumont, y que debió ser publicada por Le Courrier de la Plata luego de que se acusara a Groussac, y por extensión al diario, de antisemitismo. UN GROUPE D'ISRAÉLITES. À propos du Sionisme et de la prise de Jérusalem: LCLP. Buenos Aires, año 53, n. 196, 12 de enero de 1918, p. 3. Véase también RESNIK, S. Paul Groussac y el sionismo: Vida Nuestra. Publicación mensual israelita. Buenos Aires, n. 7, enero de 1918, p. 151-154.

15 Definida por Stéphane Audoin-Rouzeau y Annette Becker como "el campo de todas las representaciones de la guerra forjadas por los contemporáneos" (1997, p. 252), está noción fue uno de los pilares de la llamada nueva historia cultural de la Gran Guerra. Para un balance sobre los alcances y polémicas en torno a este concepto véase: (JULIEN, 2004, p. 53-68), (SMITH, 2007, p. 1067-1079) y (PURSEIGLE, 2007, p. 9-14).

16 Para una caracterización de las diferentes etapas del diario véase (OTEIZA, 2006; DÍAZ, 2018, p. 189-236). Una mirada más amplia sobre la prensa y el periodismo francófono en Buenos Aires puede consultarse en (PAPILLAUD, 1947; OTERO, 2012, p. 325-334).

17 Para una análisis más exhaustivo de esta entidad véase (REGALSKY, 2001 y 2012).

18 Véase en este sentido los porcentajes indicados en la nota n. 4.

19 Cf. SIN FIRMA. La grande Fête Française au Jockey Club. Témoignage d'amitié et d'admiration au Ministre Dr. E. Rodríguez Larreta: LCLP. Buenos Aires, año 52, n. 155, 3 de diciembre de 1916, p. 3 y 8 y Comité Patriotique Française. Souscriptions mensuelles d'Aout payées en Septembre de 1916: LCLP. Buenos Aires, año 52, n. 100, 9 de octubre de 1916, p. 5. Groussac fue también el presentador de la conferencia en el Teatro Odeón de Paul Delannoy, delegado del Instituto de Francia en viaje por América latina con el objetivo de recaudar fondos para la reconstrucción de la biblioteca de la Universidad de Lovaina, destruida por un incendio en el 
marco de la invasión alemana de Bélgica en 1914. SIN FIRMA. Pour la Bibliothèque de Louvain: LCLP. Buenos Aires, año 51, n. 291, 9 de mayo de 1916, p. 3 y SIN FIRMA. Por la Biblioteca de Lovaina. Conferencia del Sr. P. Delanoy: La Época. Diario de la tarde. Buenos Aires, n. 123, 9 de mayo de 1916, p. 4.

20 SIN FIRMA, M. Paul Groussac: LCLP. Buenos Aires, año 52, n. 162, 10 de diciembre de 1916, p. 3.

21 Sin bien, el pie de imprenta del tomo X de los Anales de la Biblioteca indica la fecha de 1915, el prefacio fue firmado por Groussac en marzo de 1916.

22 SIN FIRMA. Le nouveau rédacteur en chef du ‘Courrier de la Plata’ y C. D. [Charles Doynel]. Notre Programme: LCLP. Buenos Aires, año 52, n. 148, 23 de noviembre de 1916, p. 3.

23 De M. P. Groussac. L’Alliance Française: LCLP. Buenos Aires, año 52, n. 169, 17 de diciembre de 1916 , p. 3.

24 El Código Civil napoleónico de 1803 estableció el derecho de sangre (jus sanguinis) como criterio para definir la nacionalidad de los ciudadanos y puso fin al derecho de suelo (jus solis) de la monarquía absoluta, que estipulaba que los individuos pertenecían al soberano y que por ende perdían todos los derechos al abandonar su territorio. Por el contrario, el nuevo derecho de sangre constituía una prerrogativa inalienable de las personas y como tal no estaba circunscripta a los límites territoriales del Estado nacional. Siguiendo esta concepción, pasaron a ser considerados como franceses los hijos de padre francés aunque las hijas perdían la nacionalidad al casarse con alguien que no fuera francés. No obstante, la ley de nacionalidad de 1889 reintrodujo el jus solis lo que implicó la coexistencia de ambos criterios en la definición de la nacionalidad. La mayoría de los países de Europa adhirieron al derecho de sangre que permitía extender la nacionalidad del país de origen a los hijos de los emigrantes mientras que en los países "nuevos" como Argentina, Canadá y Estados Unidos adhirieron a la concepción del derecho de suelo como garante de la viabilidad de las naciones emergentes que debían aumentar el número de ciudadanos nativos para poner un límite a la extranjerización derivada de la inmigración masiva. Ahora bien, el hecho de que una gran proporción de los hijos de inmigrantes nacidos en Argentina no se considerara obligada a cumplir con el servicio militar obligatorio, creado en Francia en 1872, constituyó uno de los principales debates locales en tiempos de la Gran Guerra. Pues, según la orden de movilización general emitida el $1^{\circ}$ de agosto y transmitida a todos los consulados al día siguiente, debían ser convocados a filas todos los franceses aptos para el servicio de las clases 1887 a 1913 (OTERO, 2009, p. 37-38 y 113-114).

25 Véase, entre otros, los artículos de su director: C. DOYNEL. Le Statut des fils de Français I: LCLP. Buenos Aires, año 53, n. 149, 26 de noviembre de 1917, p. 3; C. DOYNEL. Le Statut des fils de Français II: LCLP. Buenos Aires, año 53, n. 151, 28 de noviembre de 1917, p. 3 y C. DOYNEL. Encore le Statut: LCLP. Buenos Aires, año 53, n. 215, 31 de enero de 1918, p. 3.

26 De M. P. Groussac. L’Alliance Française, op. cit., p. 3.

27 Véase los borradores, "Le Deux Patries. Pièce en trois actes" y "Las Dos Patrias. Escenario y borrador", Archivo Paul Groussac, Legajo n. 2, Obras literarias y comentarios sobre literatura (S/F.), AGN. Según indicaba el autor, la obra transcurre en Buenos Aires; el primer acto se sitúa el $1^{\circ}$ de agosto de 1914 mientras que el segundo y tercer acto están ambientados en octubre del mismo año.

28 En el párrafo final de la novela de Daireaux, editada en la colección de libros baratos del diario La Nación, puede leerse: “Andrés Stener repartía su corazón entre la patria de sus antepasados y la de sus hijos; á la primera conservaba su amor filial y había dado su sangre; á la otra dedicaba toda su gratitud por la felicidad que le había proporcionado; y para el bien de ambas, aseguraría á los que, en Francia, sufrían penurias ó no encontraban campo suficiente para sus ambiciones, que la Argentina era una segunda patria para todos los hombres de buena voluntad" (DAIREAUX, 1908, p. 315).

29 En este sentido, cabe recordar aquí, lo señalado por Hernán Otero en su libro sobre la movilización de la colectividad francesa de Buenos Aires: "para muchos franco-argentinos el amor a la patria se moduló en función de la lealtad a los grupos comunitarios de pertenencia y, como tal, debía resultar más una consecuencia del honor frente a los pares que de una abstracta noción ideológica, aunque ésta tuviera también su importancia. Ello adquirió más peso en personas cuya portación de apellido era indicativa de una tradición filiatoria con los notables de la comunidad (...) el costo de la deserción era para ellos mucho mayor que para un individuo no incorporado al marco comunitario o que ocupaba un lugar marginal en él” (2009, p. 176-177).

30 PAUL GROUSSAC. Lettre ouverte à Monsieur H. Jullemier: LCLP, año 54, n. 26, 27 de julio de 1918, p. 3. 


\section{Ibidem.}

32 JULLEMIER. Lettre ouverte à M. Paul Groussac: LCLP, año 54, n. 27, 28 de julio de 1918, p. 3.

\section{$33 \mathrm{lbidem}$.}

34 SIN FIRMA. Cérémonie de la remise des insignes d'Officer de la Légion d'Honneur à M. Paul Groussac y SIN FIRMA. Au Club Français: LCLP. Buenos Aires, año 54, n. 141, 19 de noviembre de 1918, p. 3. Sobre la labor de los agregados militares franceses en Argentina durante la guerra (OTERO, 2009, 69-90). Si bien es anterior al discurso de Groussac en el Club Francés, el ya citado artículo de Pierre Prud'homme iba en la misma sintonía al hacer referencias al "ardiente y sincero patriotismo" de Groussac, no obstante el cual "ha sido vilmente atacado. Y lo sigue siendo” por su adopción de la nacionalidad argentina. PRUD’HOMME, P. Monsieur Paul Groussac, op. cit.

35 LE COURRIER DE LA PLATA. A nos lecteurs: LCLP. Buenos Aires, año 54, n. 343, 30 de junio de 1919 , p. 3.

36 SIN FIRMA. A nos Lecteurs: LCLP. Buenos Aires, año 55, n. 4, 3 de julio de 1919, p. 3. Díaz (2014, p. 61) sostiene que las diferencias entre ambos grupos pueden rastrearse incluso hasta finales del siglo XIX. En 1894, desde las páginas de Le Courrier Français de Hileret, Groussac publicó un artículo contra Émile Daireaux quien envío sus padrinos para concertar un duelo que finalmente no se concretó pues el autor del texto en cuestión se disculpó públicamente. No obstante, Charles Doynel insistió con el asunto por lo que fue condenado a un año de prisión luego de que Daireaux lo llevara a juicio.

37 La única mención directa a la llamada “crisis de 1917” puede verse en: De Paul Groussac. Nos Germanophiles: LCLP. Buenos Aires, año 53, n. 141, 19 de noviembre de 1917, p. 3.

38 Véase, entre otras, SIN FIRMA. Los militares argentinos y la neutralidad: El Nacional. Diario de la tarde. Buenos Aires, n. 19526, 26 de agosto de 1914, p. 4; SIN FIRMA, Deberes ineludibles en militares y particulares: La Prensa. Diario de la mañana. Buenos Aires, n. 15994, 25 de agosto de 1914, p. 9; SIN FIRMA, Los militares argentinos y la guerra. Sus publicaciones en la prensa: La Razón. Diario de la tarde. Buenos Aires, n. 2741,22 de agosto de 1914, p. 1; SIN FIRMA, Publicaciones militares sobre la guerra: La Nación. Diario de la mañana. Buenos Aires, n. 15322, 23 de agosto 1914, p. 8; SIN FIRMA, Nuestros militares y la guerra. Resolución del ministerio: La Mañana. Diario noticioso e independiente, n. 1300, 23 de agosto de 1914, p. 12 y SIN FIRMA, La neutralidad y el cuerpo diplomático argentino: La Prensa. Diario de la mañana. Buenos Aires, n. 15979,10 de agosto de 1914, p. 7.

39 En octubre de 1915 el general Uriburu publicó en el diario La Nación un artículo sobre la batalla del Marne en el que, a modo de balance, caracterizaba el accionar del alto mando francés como de incompetente a pesar de la victoria sobre los alemanes. Cf. La guerra actual. Apuntes y enseñanzas: La Nación. Diario de la mañana. Buenos Aires, n. 15707, 17 de octubre de 1915, p. 6. El texto fue luego publicado como folleto en dos oportunidades (URIBURU, 1915; 1918). Las opiniones del militar fueron duramente criticadas en La Acción Francesa, un periódico de propaganda escrito en castellano pero bajo dirección gala. Como consecuencia de ello, Uriburu demandó por injurias a su director Louis Cogniat, que falleció poco tiempo después, y a Raimundo Manigot, jefe de redacción del citado periódico y autor de las críticas que fue condenado a un año de prisión y detenido entre enero y julio de 1918, cuando fue liberado tras el retiro de la acusación (PELOSI, 2002, p. 69-71; OTERO, 2009, p. 93-94).

40 De Paul Groussac. La haine teutonne: LCLP. Buenos Aires, n. 267, 24 de marzo de 1918, p. 3.

\section{$41 \mathrm{lbidem}$.}

42 De Paul Groussac. Comme après léna: LCLP. Buenos Aires, año 54, n. 167, 15 de diciembre de 1918, p. 3; De Paul Groussac. C'est la guerre!: LCLP. Buenos Aires, año 53, n. 43, 12 de agosto de 1917, p. 3 y De Paul Groussac. Mané, Thécel, Pharès: LCLP. Buenos Aires, año 54, n. 111, 20 de octubre de 1918, p. 3.

43 Cabe recordar que en Argentina estos acontecimientos tuvieron además una implicancia fuertemente local ya que durante el saqueo y la destrucción de la ciudad belga de Dinant, el 23 de agosto de 1914, las tropas alemanas fusilaron a Rémy Himmer, ciudadano francés y vicecónsul argentino de la ciudad, que perdió la vida junto a 31 trabajadores de su fábrica textil y ante los ojos de su familia (HORNE; KRAMER, 2001, p. 42-53). Este hecho motivó una investigación para constatar si en ese acto se había producido una violación de la neutralidad argentina y una ofensa a los símbolos patrios, cuestión que fue luego desestimada, desatando las críticas de un sector de la prensa y la opinión pública ante la "tibieza" de la política exterior del gobierno conservador 
de Victorino de la Plaza (CISNEROS; ESCUDÉ, 1999, p. 167-168; LANÚS, 2001, p. 65-66; COMPAGNON, 2014, p. 47; RINKE, 2017, p. 54).

44 De Paul Groussac. Attila: LCLP. Buenos Aires, año 53, n. 281, 7 de abril de 1918, p. 3. y De Paul Groussac. La haine teutonne, op. cit. A pesar de la extendida utilización del término boche durante la Gran Guerra, no existe un consenso respecto de su origen y sus significados. Según Christian Delporte, la palabra proviene del argot francés del siglo XIX y al parecer significaba "cabeza de madera" pero luego, al calor de un sentimiento antialemán de los años 1860, devino en alboche donde "al" opera como un diminutivo de "alemán" (DELPORTE, 2006, p. 141). Para un análisis más extenso sobre la etimología y los usos del concepto durante la Gran Guerra, véase (PROCHASSON, 2006).

45 Cf. De Paul Groussac. Attila, op. cit. y De Paul Groussac. La réligion du kaiser. Gott mit uns!: LCLP. Buenos Aires, año 52, n. 295, 22 de abril de 1917, p. 3.

46 De Paul Groussac. Lettre ouverte á George Clemenceau: LCLP. Buenos Aires, año 52, n. 323, 20 de mayo de 1917, p. 3; SIN FIRMA. Un télégramme de M. Clemenceau: LCLP. Buenos Aires, año 53, n. 353, 18 de junio de 1918, p. 3; De Paul Groussac. Devant le buste de Clemenceau: LCLP. Buenos Aires, año 54, n. 132, 10 de noviembre de 1918, p. 3 y SIN FIRMA. Au Club Français. Inauguration du buste de Clemenceau: LCLP. Buenos Aires, año 54, n. 154, 2 de diciembre de 1918, p. 3 y 4.

47 De Paul Groussac. Le Marechal Foch (Premier article): LCLP. Buenos Aires, año 54, n. 48, 18 de agosto de 1918, p. 3 y De Paul Groussac. Le Marechal Foch (Second article): LCLP. Buenos Aires, año 54, n. 55, 25 de agosto de 1918 , p. 3.

48 De Paul Groussac. La réligion du kaiser, op. cit. y De Paul Groussac. La haine teutonne, op. cit.

49 De Paul Groussac. Maximilien Harden: LCLP. Buenos Aires, año 54, n. 194, 12 de enero de 1919, p. 3.

50 En esas "reflexiones personales que me ha sugerido algunas recientes lecturas francesas", Groussac dio cuenta de las producciones de Edmond Rostand, Romain Rolland, Maurice Barrès, René Bazin, Paul Bourget, Remy de Gourmont, Marcel Prevost, Paul Margueritte y Maurice Genevoix, entre otros. Cf. De Paul Groussac. Litterature de Guerre: LCLP. Buenos Aires, año 52, n. 197, 14 de enero de 1917, p. 3. Véase, en el mismo sentido, De Paul Groussac. Les souvenirs de Léon Daudet: LCLP. Buenos Aires, año 53, n. 99,7 de octubre de 1917, p. 3 y De Paul Groussac. Marcel Prevost: LCLP, año 54, n. 97, 6 de octubre de 1918, p. 3.

51 Por sólo dar algunos ejemplos: "La propagación de nuestra lengua en el universo - y particularmente en el Nuevo Mundo - no obedece solamente a un ideal de civilización sino también a un objetivo preciso y patriótico". De M. P. Groussac. L'Alliance Française, op. cit. "Nuestro clarividente e íntegro presidente Poincaré", De Paul Groussac. 1917: LCLP. Buenos Aires, año 52, n. 183, 31 de diciembre de 1916, p. 3; De Paul Groussac. Un tournant de notre Histoire: LCLP. Buenos Aires. año 53, n. 323, 19 de mayo de 1918, p. 3 y De Paul Groussac. Notre frontière du nord-est : LCLP. Buenos Aires, año 54, n. 83, 22 de septiembre de 1918, p. 3.

52 Lejos de ser un fenómeno nacional, este incremento de la conflictividad social fue frecuente en buena parte de America latina a partir de 1918. Véase (RINKE, 2017, p. 177-184).

53 Véase, entre otras, SIN FIRMA. La nouvelle Russie: LCLP. Buenos Aires, año 52, n. 260, 18 de marzo de 1917, p. 3; SIN FIRMA. La grande Russie et sa Révolution: LCLP. Buenos Aires, año 52, n. 266, 24 de marzo de 1917, p. 3; MARNI. A. Sante Russie!: LCLP. Buenos Aires, año 52, n. 276, 3 de abril de 1917, p. 3; DE BRABANT, H. La Russie: LCLP. Buenos Aires, año 53, n. 166, 13 de diciembre de 1917, p. 3 y P. P. [Pierre Prud'homme], La Russie du moment: LCLP. Buenos Aires, año 53, n. 187, 3 de enero de 1918, p. 3.

54 De Paul Groussac. L'effondrement de la Russie: LCLP. Buenos Aires, año 53, n. 197, 13 de enero de 1918, p. 3.

$55 \mathrm{Ibidem}$.

56 Ibidem.

57 Ibidem.

58 De Paul Groussac. Washington et Lafayette: LCLP. Buenos Aires, año 53, n. 29, 29 de julio de 1917, p. 3. El arribo de esta escuadra, encargada del patrullaje de las costas sudamericanas entre Natal (Brasil) y el Río de la Plata luego del ingreso de los Estados Unidos en la guerra, se inscribe el marco de las presiones norteamericanas sobre los gobiernos neutrales del continente y, más allá de la algarabía que despertó en un 
amplio sector de la opinión pública, colocó al presidente Yrigoyen en férreo dilema diplomático pues, en rigor, la permanencia de un buque beligerante en aguas argentinas por más de 24 horas implicaba una violación de los términos de la neutralidad (CISNEROS Y ESCUDÉ, 1999, p. 98-99).

$59 \mathrm{lbidem}$.

$60 \mathrm{lbidem}$.

61 Les fêtes du 14 de Juliet. Les banquets de Club Français: LCLP. Buenos Aires, año 54, n. 14, 14 julio de 1918 , p. 3.

62 Ibidem.

$63 \mathrm{lbidem}$.

64 Ibidem, p. 4.

$65 \mathrm{lbidem}$.

66 Sobre este último aspecto véase: De Paul Groussac. Le Vallée de la Sarre: LCLP. Buenos Aires, año 54, n. 249, 9 de marzo de 1919, p. 3.

67 De Paul Groussac. Le Président Wilson et la Société des Nations: LCLP. Buenos Aires, año 54, n. 236, 23 de febrero de 1919, p. 3.

68 Ibidem y De Paul Groussac. La doctrine de Monroe: LCLP. Buenos Aires, año 54, n. 277, 6 de abril de 1919 , p. 3.

69 De Paul Groussac. Le Traité de Paix: LCLP. Buenos Aires, año 54, n. 310, 11 de mayo de 1919 y De Paul Groussac. Némesis: LCLP. Buenos Aires, año 54, n. 328, 15 de junio de 1919, p. 3.

Emiliano Gastón SANCHÉZ é Doutor em História pela Universidade de Buenos Aires. Professor da Universidade Nacional de Tres de Febrero (UNTREF) e Pesquisador do Consejo Nacional de Investigaciones Científicas y Técnicas (CONICET). Este artigo forma parte do projeto de pesquisa "Representaciones de la Gran Guerra en la prensa periódica argentina (1914-1919). Los diarios de las colectividades extranjeras y del interior del país", desenvolvido no Programa de Estudos de Pós-Doutorado da Universidade Nacional de Tres de Febrero e contou com financiamento do projeto PICT 2015-3029: "La prensa y la opinión pública argentina ante la Gran Guerra (19141919). Debates, alineamientos y representaciones a la luz de la prensa étnica y los diarios del interior del país". 